\title{
Aplikasi Model Wavelet Neuro Fuzzy untuk Memprediksi Banjir Sungai Bengawan Solo
}

\author{
Nurmalitasari ${ }^{1}$, Sri Sumarlinda ${ }^{2}$
}

1,2 STMIK Duta Bangsa Surakarta, Indonesia

Correspondence: $\square$ nurmalitasari@stmikdb.ac.id

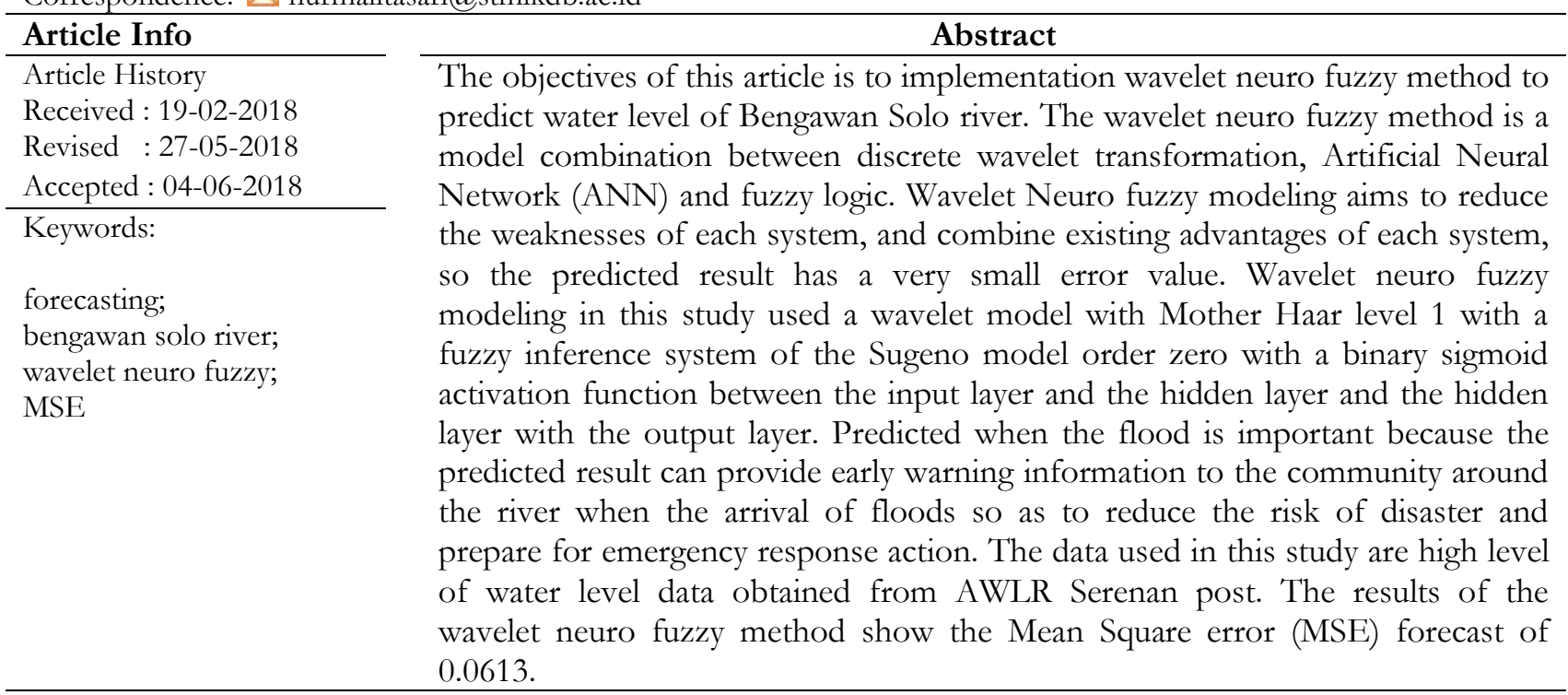

\section{PENDAHULUAN}

Sejak tahun 1863 Bengawan Solo telah menimbulkan banjir di daerah hulu, bahkan saat ini banjir sudah masuk kawasan hilir. Banjir akibat luapan sungai Bengawan Solo terakhir terjadi bulan april 2015 dan ribuan rumah kebanjiran tersebar di sejumlah daerah. Kejadian banjir menyebabkan kerugian bagi masyarakat di sekitar sungai baik kerugian harta benda maupun nyawa [1]. Banjir merupakan fenomena alam yang tidak dapat dicegah, tetapi dapat dikurangi [2]. Salah satu upaya penanggulangan banjir adalah memberikan informasi peringatan dini kepada masyarakat disekitar sungai kapan waktu datangnya banjir. Peringatan dini merupakan pengambilan tindakan cepat dan tepat dalam rangka mengurangi risiko terkena bencana serta mempersiapkan tindakan tanggap darurat [3]. Dengan adanya peringatan dini penduduk sekitar sungai Bengawan Solo memiliki kesempatan untuk menyelamatkan diri dan harta bendanya. Mengingat begitu pentingnya informasi tentang kapan terjadinya banjir, maka dalam penelitian ini akan memprediksi tinggi muka air (TMA) sungai Bengawan Solo.

Penggunaan metode yang sesuai untuk melakukan prediksi mempunyai beberapa faktor yang berpengaruh yaitu waktu, pola data, hubungan antara dengan data sebelumnya dan tingkat keakuratan ramalan yang diinginkan. Dewasa ini berkembang metode baru dalam peramalan yang menghasilkan error sangat kecil yaitu metode wavelet neuro fuz:y [4][6]. Metode wavelet neuro fuz:y merupakan penggabungan model antara transformasi wavelet diskrit dan neuro furzy. Tranformasi wavelet diskrit merupakan metode yang mendekomposisikan sebuah data diskrit ke dalam beberapa data baru yang memiliki korelasi terhadap data sebelumnya [4][6]. Metode selanjutnya, neuro furay adalah penggabungan 
dua sistem, yaitu Artificial Neural Network (ANN) atau jaringan syaraf tiruan dengan logika furay [7] [8]. Sedangkan, logika fur:y merupakan representasi pengetahuan yang dikonstruksikan dengan IF-THEN rules [9]. Pemodelan wavelet neuro fuz:y bertujuan untuk mengurangi kelemahan dari masing-masing sistem, serta menggabungkan kelebihan yang ada dari masing-masing system [4][6].

Prediksi dengan menggunakan metode wavelet neuro fuzzy pernah dilakukan dalam memprediksi curah hujan harian [6], memprediksi dan emulation tugas [4], memprediksi nilai tukar Euro terhadap dollar Amerika [10], memprediksi banjir di sungai Fahlian dengan menggunakan data Runoff [5]. Hasil dari penelitian-penelitian tersebut menunjukkan nilai error yang sangat kecil. Melihat hal tersebut, dalam memprediksi banjir sungai Bengawan Solo, peneliti tertarik untuk menggunakan metode wavelet neuro furay.

\section{METODE}

Data yang digunakan dalam penelitian ini adalah data tinggi muka air yang diperoleh dari pos AWLR Serenan tanggal 1-30 Oktober 2016. Metode peramalan yang digunakan dalam penelitian ini adalah metode wavelet neuro fuzry. Langkah-langkah peramalan menggunakan wavelet neuro furay adalah sebagai berikut [11]

\section{1) Mentransformasi Data}

Transformasi data menggunakan wavelet mother Haar level 1 dengan menggunakan DW'T pada data sebenarnya. Data nilai tukar sebenarnya didekomposisikan ke beberapa banyaknya DWs tertentu yang masing-masing mempunyai kontribusi berbeda terhadap data sebenarnya. DWs yang signifikan diperoleh berdasarkan besarnya nilai koefisien korelasi. Koefisien korelasi akan memberikan informasi terhadap DWs yang dipilih dengan data sebenarnya tentang pemilihan model input. Ditentukan $r \geq 0.5$ sebagai korelasi yang signifikan antara data DWs dengan data sebenarnya. Hasil penjumlahan dari beberapa DWs yang signifikan tersebut berdasarkan nilai korelasi yang diperoleh akan digunakan sebagai input model prediksi.

\section{2) Menentukan Banyaknya Input Model}

Pada penelitian ini, Autocorrelation Function (ACF) atau fungsi autokorelasi digunakan untuk menentukan banyaknya input yang akan digunakan pada sebuah model. Banyaknya input ditentukan dengan banyaknya lag yang keluar melebihi batas garis signifikansi.

\section{3) Memilih Variabel Input-output pada Data Pelatihan}

Proses ini menggunakan metode eliminasi backward dengan fungsi biaya Sum Square Error (SSE). Seleksi variabel dilakukan dengan cara mengeliminasi variabel-variabel yang tidak diperlukan dan mempertahankan variabel-variabel yang memberikan korelasi yang cukup signifikan terhadap variabel output yi.

\section{4) Mengelompokkan (Clustering) Data Pelatihan}

Proses clustering membagi data TRD menjadi $r$ kelas dengan menggunakan metode pengclusteran Furay C-Means (FCM). FCM adalah teknik pengclusteran data dimana tiap data dalam suatu cluster ditentukan oleh derajat keanggotaannya.

5) Pembelajaran jaringan syaraf yang berhubungan dengan bagian anteseden (bagian IF) pada aturan-aturan inferensi fuzzy

Setiap vektor input pada data TRD, ditentukan $m_{i}=\left(m_{i}^{1}, m_{i}^{2}, \ldots, m_{i}^{r}\right), i=1,2, \ldots, N_{s}$ dengan aturan furzy sebagai berikut [11]: 
dengan

$$
m_{i}^{k}=\left\{\begin{array}{l}
1 ; k=s \\
0 ; k \neq s
\end{array}\right.
$$

$m_{i}^{k}=$ derajat keanggotaan tiap data $\left(x_{i}\right)$ pada cluster ke- $k(k \leq r)$

$s=$ banyaknya aturan inferensi furzy

Derajat keanggotaan tiap data dapat diperoleh sebagai output jaringan yang telah dilatih sebagai [11]:

$$
\mu_{A s} x_{i}=m_{i}^{s}
$$

dengan $i=1,2, \ldots, \mathrm{N}, s=1,2, \ldots, r$ dan $\mu_{A s}$ adalah nilai keanggotaan tiap data dalam himpunan furzy A pada aturan fur:y ke-s bagian anteseden.

6) Pembelajaran jaringan syaraf yang berhubungan dengan bagian konsekuen (bagian THEN) pada aturan-aturan inferensi fuzzy.

Pada bagian ini, akan dilakukan pembelajaran jaringan syaraf pada bagian THEN dari $R^{s}$ dengan input $x=\left(x_{i 1}^{s}, x_{i 2}^{S}, \ldots, x_{i m}^{s}\right), i=1,2, \ldots, N c$ dan target output $y_{i}^{s}, i=1,2, \ldots . N s$. Selanjutnya hasil pelatihan akan diujikan pada data $C H D$ dengan input $x=\left(x_{i 1}^{S}, x_{i 2}^{S}, \ldots, x_{i m}^{S}\right), i=1,2, \ldots, N c$ untuk mendapatkan SSE CHD sebagai berikut (Lin. 1996):

untuk $\mathrm{s}=1,2, \ldots, r$ dengan

$$
E_{m}^{s}=\sum_{i=1}^{N c}\left[y_{i}-f_{s}\left(x_{i}\right) \mu_{A s}\left(x_{i}\right)\right]^{2}
$$

$r=$ banyaknya kelas

$y_{i}=$ target output ke- $i$

$N_{c}=$ banyak pasangan data CHD

$\mu A s(x i)=$ derajat keanggotaan tiap $x i$ dalam himpunan furay $A$ pada aturan furzy ke-s bagian anteseden

$f s(x i)=$ Output jaringan hasil pembelajaran tiap $x i$ pada setiap aturan inferensi fursy $R^{s}$ pada bagin konsekuen

Selanjutnya, error dengan pembobotan dapat dihitung sebagai berikut:

$$
E_{m}^{s}=\sum_{i=1}^{N c} \mu_{A s}\left(x_{i}\right)\left[y_{i}-f_{s}\left(x_{i}\right) \mu_{A s}\left(x_{i}\right)\right]^{2}
$$

\section{7) Menyederhanakan bagian konsekuen (bagian THEN) menggunakan metode backward}

Dari semua variabel input yang terpilih tidak semua variabel berpartisipasi pada neural network. memiliki kontribusi yang cukup baik. Oleh karena itu, salah satu variabel dapat dieliminasi untuk mendapatkan hasil output yang lebih baik dan kemudian melatih jaringan kembali untuk mendapatkan $\operatorname{SSE}\left(E_{m}^{s p}\right)$ sebagai berikut (Lin, 1995):

$$
E_{m}^{s p}=\sum_{i=1}^{N c}\left[y_{i}-f_{s}\left(x_{i}\right) \mu_{A s}\left(x_{i}\right)\right]^{2}
$$

untuk $p=1,2, \ldots, m$ dengan, 
Numerical: Jurnal Matematika dan Pendidikan Matematika, Vol. 2 No. 1 Desember 2018, 21-30

Nurmalitasari, Sri Sumarlinda

$r=$ banyaknya kelas

$y_{i}=$ target output ke- $i$

$N c=$ banyak pasangan data $\mathrm{CHD}$

$\mu_{A s}\left(x_{i}\right)=$ derajat keanggotaan tiap $x_{i}$ dalam himpunan furay Apada aturan furzy ke-s bagian anteseden dengan eliminasi variable imput $x_{p}$

$f_{s}\left(x_{i}\right)=$ Output jaringan hasil pembelajaran tiap $x_{i}$ pada setiap aturan inferensi furzy

$R^{s}$ pada bagian konsekuen dengan eliminasi variable input $x_{p}$.

Jika $E_{m}^{S}>E_{m}^{s p}$ terpenuhi akan ditentukan parameter konsekuen untuk tiap $R^{s}$ dengan menggunakan metode Least Square Estimator (LSE) untuk mengidentifikasi parameter-parameter linearnya. LSE merupakan pembelajaran off-line dengan menggunakan metode invers.

\section{8) Menentukan Output Akhir}

Nilai $y_{i} *$ akhir dapat diperoleh sebagai berikut [11]:

dengan. $i=1,2, \ldots, N$

$$
y_{i} *=\frac{\sum_{s=1}^{r} f_{s}\left(x_{i}\right) \mu_{A s}\left(x_{i}\right)}{\sum_{s=1}^{r} \mu_{A s}\left(x_{i}\right)}
$$

$$
\begin{aligned}
& y_{i} *=\text { output akhir } \\
& \mu_{A s}\left(x_{i}\right)=\text { derajat keanggotaan tiap } x i \text { dalam himpunan furzy } A \text { pada aturan furzy ke-s } \\
& \text { bagian anteseden } \\
& f_{s}\left(x_{i}\right)=\text { Output jaringan hasil pembelajaran tiap } x_{i} \text { pada setiap aturan inferensi furay } \\
& R^{S} \text { pada bagian konsekuen }
\end{aligned}
$$

\section{9) Mengukur Kesalahan Peramalan}

Untuk mengecek besar kesalahan peramalan, dapat diketahui dengan menghitung selisih antara nilai asli dengan nilai peramalannya, yang dikenal dengan nama error atau galat. Dalam penelitian ini cara pengukuran yang digunakan untuk mengetahui besarnya kesalahan yang dihasilkan oleh model peramalan menggunakan Mean Square Error (MSE).

$$
M S E=\frac{1}{n} \sum_{i=1}^{n}(Y-\hat{Y})^{2}
$$

\section{HASIL DAN PEMBAHASAN}

Pada penelitian ini, model wavelet neuro fuzay adalah model wavelet dengan Mother Haar level 1 dengan sistem inferensi furay model Sugeno. Data yang digunakan dalam penelitian ini adalah data Tinggi Muka Air (TMA) dari pos AWRL Serenan pada tanggal 1-30 Oktober 2016. Model Wavelet Neuro Furzy yang digunakan dalam penelitian ini adalah model wavelet neuro furzy sugeno orde nol dengan fungsi aktivasi sigmoid biner antara lapisan input dengan lapisan tersembunyi dan lapisan tersembunyi dengan lapisan output. Langkah-langkah peramalan banjir menggunakan wavelet neuro furgy sugeno orde nol dengan fungsi aktivasi sigmoid biner antara lapisan input dengan lapisan tersembunyi dan lapisan tersembunyi dengan lapisan output adalah sebagai berikut.

\section{a. Proses Transformasi Data}

Proses transformasi wavelet mendekomposisikan data sebenarnya menjadi data DW1 (d) dan data approximation (a). langkah selanjutnya menghitung korelasi antara approximation dengan data sebenarnya (tma) dan antara DW1 dengan tma. Korelasi antara data approximation dengan data tma 
sebesar 0.914. Sedangkan korelasi antara data DW1 dengan data tma sebesar 0.406. Dari hasil perhitungan korelasi approximation dan DW1 dengan data sebenarnya diperoleh korelasi yang paling besar adalah korelasi antara data approxtimation dengan tma. Sehingga nilai approxtimation digunakan sebagai input dari model neuro fuzzy.

Tabel 1. DWs yang digunakan sebagai input neuro fuzzy.

\begin{tabular}{cccc}
\hline $\mathbf{t}$ & $\mathbf{D W s}$ & $\mathbf{t}$ & $\mathbf{D W s}$ \\
\hline 1 & 1.425 & 16 & 2.475 \\
\hline 2 & 1.425 & 17 & 1.775 \\
\hline 3 & 2.375 & 18 & 1.775 \\
\hline 4 & 2.375 & 19 & 1.335 \\
\hline 5 & 1.825 & 20 & 1.335 \\
\hline 6 & 1.825 & 21 & 1.305 \\
\hline 7 & 1.45 & 22 & 1.305 \\
\hline 8 & 1.45 & 23 & 1.45 \\
\hline 9 & 2.775 & 24 & 1.45 \\
\hline 10 & 2.775 & 25 & 1.515 \\
\hline 11 & 1.925 & 26 & 1.515 \\
\hline 12 & 1.925 & 27 & 1.65 \\
\hline 13 & 1.655 & 28 & 1.65 \\
\hline 14 & 1.655 & 29 & 1.77 \\
\hline 15 & 2.475 & 30 & 1.77 \\
\hline
\end{tabular}

\section{b. Penentuan banyaknya input model}

Data input ditentukan dengan menggunakan plot fungsi autokorelasi (ACF) dari hasil DWT. Banyaknya lag yang keluar atau melebihi batas garis signifikansi menunjukkan banyaknya variabel yang akan digunakan dalam membangun model.

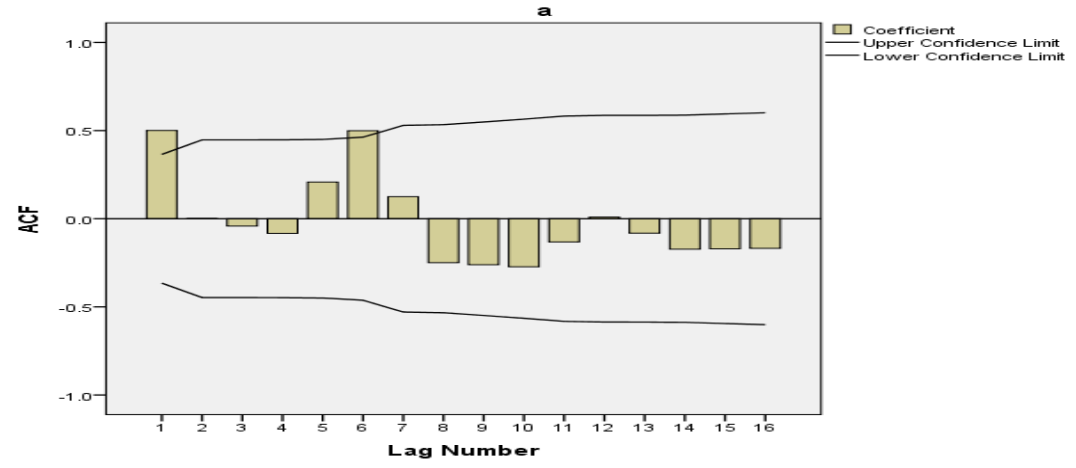

Gambar 1. Diagram ACF

Berdasarkan Gambar 1, lag yang keluar ada pada lag ke-1 dan 6, sehingga model yang akan dibangun menggunakan 2 variabel input dengan 28 pasang data. Input yang digunakan adalah lag ke-1 sebagai input pertama $\left(x_{1}\right)$ dan lag ke-6 sebagai input kedua $\left(x_{2}\right)$.

\section{c. Pemilihan variabel input-output pada data pelatihan}

Pemilihan variabel input dan output ditetapkan dengan pemilihan variabel input $x_{1}$ dan $x_{2}$ yang berhubungan dengan $y_{j}, j=1,2,3, \ldots, 30$ menggunakan jaringan backpropagation dengan metode 
eliminasi backward dan fungsi biaya SEE. Pasangan input-input sebanyak 28 data yang telah dipilih. Selanjutnya 28 pasang data tersebut dibagi menjadi 2 yaitu Training data (TRD) dan Cheking data (CHD) dengan komposisi pembagian yang digunakan adalah 75\% untuk TRD dan 25\% untuk CHD. Data TRD terdapat 21 pasang seperti pada tabel 2. dan data CHD terdapat 7 pasang seperti pada tabel 3 .

Tabel 2. Tabel pasangan TRD Input dan Output data tma.

\begin{tabular}{|c|c|c|c|c|c|c|c|}
\hline \multirow{2}{*}{$\begin{array}{l}\text { Data } \\
\text { Ke- }\end{array}$} & \multicolumn{2}{|c|}{ Variabel Input } & \multirow{2}{*}{$\begin{array}{c}\text { Target } \\
\text { Output (y) }\end{array}$} & \multirow{2}{*}{$\begin{array}{l}\text { Data } \\
\text { Ke- }\end{array}$} & \multicolumn{2}{|c|}{ Variabel Input } & \multirow{2}{*}{$\begin{array}{c}\text { Target } \\
\text { Output } \\
(y)\end{array}$} \\
\hline & $x_{2}$ & $x_{1}$ & & & $x_{2}$ & $x_{1}$ & \\
\hline 1 & 1.425 & 1.425 & 2.9 & 12 & 1.925 & 1.655 & 1.69 \\
\hline 2 & 1.425 & 2.375 & 1.85 & 13 & 1.655 & 1.655 & 2.4 \\
\hline 3 & 2.375 & 2.375 & 2 & 14 & 1.655 & 2.475 & 2.55 \\
\hline 4 & 2.375 & 1.825 & 1.65 & 15 & 2.475 & 2.475 & 1.9 \\
\hline 5 & 1.825 & 1.825 & 1.5 & 16 & 2.475 & 1.775 & 1.65 \\
\hline 6 & 1.825 & 1.45 & 1.4 & 17 & 1.775 & 1.775 & 1.52 \\
\hline 7 & 1.45 & 1.45 & 2.5 & 18 & 1.775 & 1.335 & 1.15 \\
\hline 8 & 1.45 & 2.775 & 3.05 & 19 & 1.335 & 1.335 & 1.4 \\
\hline 9 & 2.775 & 2.775 & 2 & 20 & 1.335 & 1.305 & 1.21 \\
\hline 10 & 2.775 & 1.925 & 1.85 & 21 & 1.305 & 1.305 & 1.42 \\
\hline 11 & 1.925 & 1.925 & 1.62 & & & & \\
\hline
\end{tabular}

Tabel 3. Tabel pasangan CHD Input dan Output data tma.

\begin{tabular}{|c|c|c|c|}
\hline \multirow[b]{2}{*}{ Data Ke- } & \multicolumn{2}{|c|}{ Variabel Input } & \multirow{2}{*}{$\begin{array}{c}\text { Target Output } \\
(y)\end{array}$} \\
\hline & $x_{2}$ & $x_{1}$ & \\
\hline 1 & 1.45 & 1.45 & 1.48 \\
\hline 2 & 1.45 & 1.515 & 1.41 \\
\hline 3 & 1.515 & 1.515 & 1.62 \\
\hline 4 & 1.515 & 1.65 & 1.75 \\
\hline 5 & 1.65 & 1.65 & 1.55 \\
\hline 6 & 1.65 & 1.77 & 2 \\
\hline 7 & 1.77 & 1.77 & 1.54 \\
\hline
\end{tabular}

Seleksi variabel dilakukan dengan cara mengeliminasi variabel-variabel yang tidak diperlukan dan mempertahankan variabel-variabel yang memberikan korelasi yang cukup signifikan terhadap variabel output $y_{i}$. Proses tersebut dilakukan dengan menentukan nilai SSE terkecil pada setiap variabel yang dieliminasi. Sebelum menghitung nilai SSE TRD, terlebih dahulu perlu dilakukan perhitungan untuk mengetahui jumlah neuron pada lapisan tersembunyi. Pemilihan jumlah neuron pada lapisan tersembunyi dilakukan dengan perhitungan terhadap nilai Mean Square Error (MSE) pada TRD. Nilai MSE terkecil akan menetapkan jumlah neuron yang akan digunakan pada model jaringan. Tabel 4 berikut adalah hasil perhitungan SSE data TRD dan CHD. 
Numerical: Jurnal Matematika dan Pendidikan Matematika, Vol. 2 No. 1 Desember 2018, 21-30

Nurmalitasari, Sri Sumarlinda

Tabel 4. Perbandingan SSE data TRD dan CHD

\begin{tabular}{cc}
\hline Variabel yang dieliminasi & SSE \\
\hline Tidak ada yang dieliminasi & 5.526 \\
\hline$x_{1}$ & 5.500 \\
\hline$x_{2}$ & 6.773
\end{tabular}

SSE yang diperoleh pada saat variabel $x_{1}$ dieliminasi cukup kecil sehingga penghapusan $x_{1}$ akan memberikan model yang lebih baik, sehingga variabel input yang berpartisipasi pada bagian anteseden (bagian If) adalah variabel $x_{2}$ dengan target output $y_{i}$.

\section{d. Pengelompokan (Clustering) data pelatihan}

Pada bagian ini, data TRD dan CHD akan dibagi menjadi $r$ kelas $(r \geq 2)$ dengan menggunakan metode pengclusteran FCM, sehingga akan memiliki $r$ buah aturan $R^{s}, s=1,2, \ldots, r$. Dalam penelitian ini data TRD dan CHD akan dibagi menjadi 2 kelas, sehingga diperoleh 2 buah aturan $R^{S}$, s $=1,2$. Pasangan input dan output pada aturan ke-s direpresentasikan sebagai $\left(x_{i}^{S}, y_{i}^{s}\right), i=1,2, \ldots, N_{s}$ dengan $N_{s}$ adalah jumlah data yang masuk pada kelas ke-s. Berdasarkan hasil clustering, diperoleh nilai keanggotaan setiap data pada setiap cluster dan kecenderungan suatu data masuk ke suatu cluster seperti tabel 5 dan 6 berikut.

Tabel 5. Nilai keanggotaan data TRD pada cluster tertentu

\begin{tabular}{|c|c|c|c|c|c|c|c|c|c|}
\hline \multirow[t]{2}{*}{ Data } & \multicolumn{2}{|c|}{ Matriks } & \multirow[t]{2}{*}{ Maks } & \multirow[t]{2}{*}{ Cluster } & \multirow[t]{2}{*}{ Data } & \multicolumn{2}{|c|}{ Matriks } & \multirow[t]{2}{*}{ Maks } & \multirow[t]{2}{*}{ Cluster } \\
\hline & & Partisi & & & & & Partisi & & \\
\hline $\mathrm{Ke}-$ & $\mu_{i 1}$ & $\mu_{i 2}$ & $\mu_{i k}$ & $\mathrm{Ke}-$ & $\mathrm{Ke}-$ & $\mu_{i 1}$ & $\mu_{i 2}$ & $\mu_{i k}$ & $\mathrm{Ke}-$ \\
\hline 1 & 0.073 & 0.927 & 0.927 & 2 & 12 & 0.985 & 0.015 & 0.985 & 1 \\
\hline 2 & 0.577 & 0.423 & 0.577 & 1 & 13 & 0.029 & 0.971 & 0.971 & 2 \\
\hline 3 & 0.729 & 0.271 & 0.729 & 1 & 14 & 0.004 & 0.996 & 0.996 & 2 \\
\hline 4 & 0.893 & 0.107 & 0.893 & 1 & 15 & 0.77 & 0.23 & 0.77 & 1 \\
\hline 5 & 0.975 & 0.025 & 0.975 & 1 & 16 & 0.858 & 0.142 & 0.858 & 1 \\
\hline 6 & 0.961 & 0.039 & 0.961 & 1 & 17 & 0.962 & 0.038 & 0.962 & 1 \\
\hline 7 & 0.019 & 0.981 & 0.981 & 2 & 18 & 0.896 & 0.104 & 0.896 & 1 \\
\hline 8 & 0.105 & 0.895 & 0.895 & 2 & 19 & 0.756 & 0.244 & 0.756 & 1 \\
\hline 9 & 0.673 & 0.327 & 0.673 & 1 & 20 & 0.771 & 0.229 & 0.771 & 1 \\
\hline 10 & 0.723 & 0.277 & 0.723 & 1 & 21 & 0.739 & 0.261 & 0.739 & 1 \\
\hline 11 & 0.997 & 0.003 & 0.997 & 1 & & & & & \\
\hline
\end{tabular}

Tabel 6. Kecenderungan data CHD pada cluster tertentu

\begin{tabular}{ccccc}
\hline \multirow{2}{*}{$\begin{array}{c}\text { Data } \\
\text { ke- }\end{array}$} & \multicolumn{2}{c}{ Matriks partisi } & & \\
\cline { 2 - 4 } & $\boldsymbol{\mu}_{\boldsymbol{i} \mathbf{1}}$ & $\boldsymbol{\mu}_{\boldsymbol{i} \mathbf{2}}$ & Maks $\boldsymbol{\mu}_{\boldsymbol{i} \boldsymbol{k}}$ & Cluster ke- \\
\hline 1 & 0.944 & 0.056 & 0.944 & 1 \\
\hline 2 & 0.920 & 0.080 & 0.920 & 1 \\
\hline 3 & 0.905 & 0.095 & 0.905 & 1 \\
\hline 4 & 0.414 & 0.586 & 0.586 & 2 \\
\hline 5 & 0.928 & 0.072 & 0.928 & 1 \\
\hline
\end{tabular}

Copyright (C) 2018, Numerical: Jurnal Matematika dan Pendidikan Matematika Print ISSN: 2580-3573, Online ISSN: 2580-2437 
Numerical: Jurnal Matematika dan Pendidikan Matematika, Vol. 2 No. 1 Desember 2018, 21-30

Nurmalitasari, Sri Sumarlinda

\begin{tabular}{lllll}
\hline 6 & 0.038 & 0.962 & 0.962 & 2 \\
\hline 7 & 0.770 & 0.230 & 0.770 & 1 \\
\hline
\end{tabular}

e. Pembelajaran jaringan syaraf yang berhubungan dengan bagian anteseden (bagian IF) pada aturan-aturan inferensi fuzzy.

Setiap vector pada data TRD dan CHD, ditentukan $m_{i}=\left(m_{i}^{1}, m_{i}^{2}, \ldots, m_{i}^{r}\right), i=1,2, \ldots, 21, r=$ banyaknya kelas, untuk data TRD dan $i=1,2, \ldots, 7$ untuk data CHD. Selanjutnya akan dilatih jaringan syaraf tiruan dengan variabel imput $x_{2}$ dengan target output $m_{1}$ dan $m_{2}$ menggunakan metode backpropagation, fungsi aktifasi sigmoid bipolar dengan satu lapisan tersembunyi, parameter yang digunakan adalah maksimum epoh $=50$, laju pembelajaran $=1$ dan toleransi eror $=10^{-6}$, dengan banyaknya neuron pada lapisan tersembunyi pada penelitian ini menggunakan 1 input. Hasil pembelajaran berupa suatu nilai keanggotaan setiap data pada himpunan fuzzy A pada aturan fuzzy ke-s bagian anteseden. $\mu_{A s}\left(x_{i}\right)=\widehat{m}_{i}^{S} ; i=1,2, \ldots N ; s=1,2, \ldots, r$. Hasil pembelajarannya dapat dilihat dalam tabel 5.81 berikut.

Tabel 5.81 Nilai Keanggotaan pada bagian IF $\left(\mu_{A s}\right)$ TRD \& CHD

\begin{tabular}{|c|c|c|c|c|c|}
\hline \multirow{2}{*}{$\begin{array}{l}\text { Data } \\
\text { Ke- }\end{array}$} & \multicolumn{2}{|c|}{ Nilai Keanggotaan } & \multirow{2}{*}{$\frac{\text { Data }}{\mathrm{Ke}-}$} & \multicolumn{2}{|c|}{ Nilai Keanggotaan } \\
\hline & $\mu_{A 1}$ & $\mu_{A 2}$ & & $\mu_{A 1}$ & $\mu_{A 2}$ \\
\hline 1 & 0.73427 & 0.534998 & 15 & 0.728239 & 0.368341 \\
\hline 2 & 0.525417 & 0.690436 & 16 & 0.805642 & 0.150389 \\
\hline 3 & 0.899928 & 0.259985 & 17 & 0.456985 & 0.576987 \\
\hline 4 & 0.901738 & 0.145845 & 18 & 0.805995 & 0.111831 \\
\hline 5 & 0.878942 & 0.160917 & 19 & 0.4996 & 0.533178 \\
\hline 6 & 0.883612 & 0.088155 & 20 & 0.770107 & 0.164245 \\
\hline 7 & 0.790417 & 0.294874 & 21 & 0.796418 & 0.082579 \\
\hline 8 & 0.583958 & 0.618724 & 22 & 0.87374 & -0.152765 \\
\hline 9 & 0.85803 & 0.269222 & 23 & 0.872358 & -0.083023 \\
\hline 10 & 0.863105 & 0.153083 & 24 & 0.887911 & -0.10089 \\
\hline 11 & 0.741868 & 0.361793 & 25 & 0.888174 & -0.055453 \\
\hline 12 & 0.811706 & 0.158686 & 26 & 0.863888 & 0.357202 \\
\hline 13 & 0.725732 & 0.296987 & 27 & 0.876676 & 0.225351 \\
\hline 14 & 0.328436 & 0.709307 & 28 & 0.855406 & 0.47831 \\
\hline
\end{tabular}

\section{f. Pembelajaran jaringan syaraf yang berhubungan dengan bagian konsekuen (bagian THEN) pada aturan-aturan inferensi fuzzy.}

Pada bagian ini akan dilakukan pembelajaran jaringan syaraf pada bagian THEN dari $R^{S}$ dengan input $x=\left(x_{i 1}^{S}, x_{i 2}^{S}, x_{i 3}^{S}, \ldots, x_{i m}^{S}\right)$ dan target output $y_{i}^{S}, i=1,2, \ldots, 21 ; s=1,2$. Proses pembelajaran dibagi menjadi 2 proses pembelajaran sesuai dengan jumlah cluster yang ditentukan, yaitu $R^{1}\left(N N_{1}\right)$, dan $R^{2}\left(N_{2}\right)$. Proses selanjutnya adalah pembelajaran tiap $N N s$ menggunakan jaringan Bacpropagation lavenbergh marquardt dengan 1 lapisan tersembunyi, dengan parameter: maksimum epoh $5, \mu=0.75$ dan $\beta=2$, dan toleransi error $=10^{-6}$. Fungsi aktivasi yang digunakan antara lapisan input dengan lapisan tersembunyi adalah fungsi sigmoid biner yang juga untuk lapisan antara lapisan tersembunyi dan lapisan output. 


\section{g. Penyederhanaan bagian konsekuen (bagian THEN) menggunakan metode eliminasi backward}

Dalam penelitian ini bagian penyederhanaan bagian konsekuen tidak dilakukan, karena hanya mengandung satu variabel input saja yaitu $x_{2}$, jadi tidak ada variabel lain yang dieliminasi.

\section{h. Penentuan Output akhir}

Hasil prediksi banjir sungai Bengawan Solo dapat dilihat pada gambar 2 berikut.

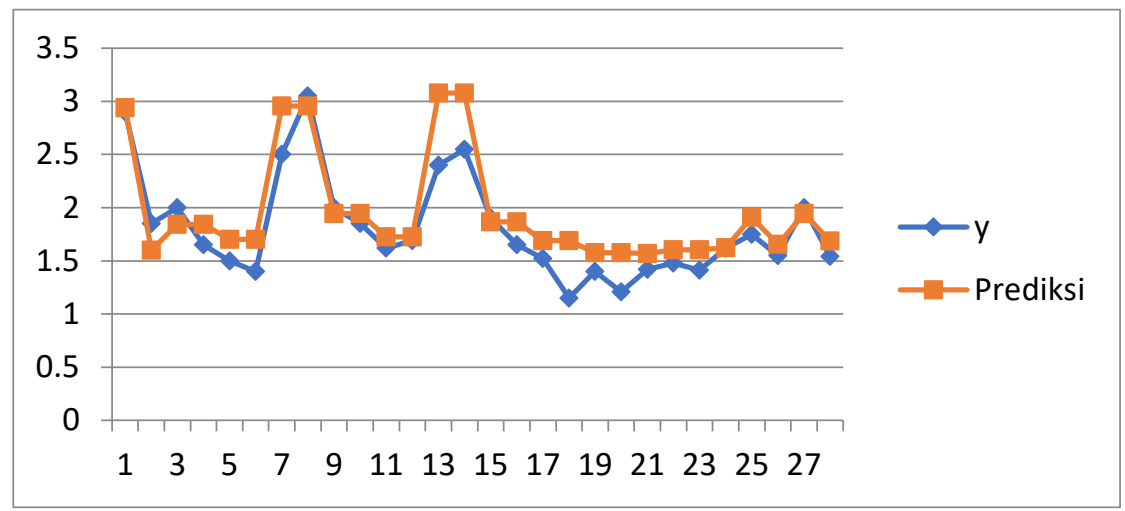

\section{i. Penentuan MSE}

Gambar 2. prediksi banjir sungai Bengawan Solo

Nilai MSE hasil prediksi banjir sungai Bengawan Solo adalah sebagai berikut.

$$
M S E=\frac{1}{n} \sum_{i=1}^{n}\left(Y_{i}-Y_{i}^{*}\right)^{2}=0.0613
$$

\section{SIMPULAN DAN SARAN}

Berdasarkan uraian hasil penelitian dan pembahasan maka penulis dapat memberikan kesimpulan bahwa model wavelet neuro furay dapat diterapkan untuk memprediksi banjir sungai Bengawan Solo. Dalam penerapannya model wavelet yang digunakan adalah Mother Haar level 1 dengan sistem inferensi furzy model Sugeno orde nol dengan fungsi aktivasi sigmoid biner antara lapisan input dengan lapisan tersembunyi dan lapisan tersembunyi dengan lapisan output. Hasil prediksi dengan menggunakan metode wavelet Neuro Fuz:y diperoleh nilai Mean Square Error (MSE) adalah 0.0613. Saran yang diajukan dari hasil penelitian ini adalah memperbanyak data training wavelet Neuro Fuz:y untuk meningkatkan performa dari struktur wavelet Neuro Fuzay yang disusun.

\section{DAFTAR PUSTAKA}

[1] B. N. P. B. RI, “Data Bencana Indonesia,” Jkt. BNPB, 2015.

[2] A. Findayani, "Kesiapsiagaan Masyarakat Dalam Penanggulangan Banjir Di Kota Semarang," J. Geogr. Media Infromasi Pengemb. Ilmu Dan Profesi Kegeografian, Jan. 2015.

[3] Dewan Perwakilan Rakyat Republik Indonesia and Presiden Republik Indonesia, Undang-Undang Republik. Indonesia Nomor 24 Tabun 2007 Tentang Penanggulangan Bencana Dengan Rabmat Tuban Yang Maba Esa Presiden Republik. Indonesia. . 
[4] Y. Bodyanskiy, I. Pliss, and O. Vynokurova, "Adaptive wavelet-neuro-fuzzy network in the forecasting and emulation tasks," Int J. Inf. Theory Appl., vol. 15, no. 1, pp. 47-55, 2008.

[5] Fereydooni, M. and Pezhman, S, "Use Of Hybrid Wavelet-Neural And Wavelet Neuro-Fuzzy Model In Simulation Of Rate Of Flow Of River (Study Case: Fahlian River)," Indian J. Fundam. Appl. Life Sci., vol. 5, no. 3, pp. 692-701, 2015.

[6] Ö. Kişi, "Streamflow forecasting using different artificial neural network algorithms," J. Hydrol. Eng., vol. 12, no. 5, pp. 532-539, 2007.

[7] L. Fausset, "Fundamentals of neural networks," Archit. Algorithm Appl. Prentice Hall, 1994.

[8] Nabizadeh M, Mosaedi A, and Dehghani A, "Intelligent estimation of rate of flow by utilizing ANFIS (Adaptive-Network-Based Fuzzy Inference System)," Water Irrig. Manag., vol. 2, no. 1, pp. 69-80, 2011.

[9] Sielvy E., "Aplikasi Model Neuro Fuzzy untuk Memprediksi Harga Emas," Skripsi, UNY, Yogyakarta, 2013.

[10] A. Setiaji, "Aplikasi model wavelet-neuro-fuzzy untuk memprediksi nilai tukar euro terhadap dollar amerika," PhD Thesis, UNY, 2014.

[11] C.-T. Lin and C. G. Lee, “Neural fuzzy systems,” PTR Prentice Hall, 1996. 